\title{
Plasma atrial natriuretic peptide in patients with acute myocardial infarction: effects of streptokinase
}

\author{
P A PHILlips, J SASADEUS, * G P HODSMAN, J HOROWITZ, A SALTUPS, * \\ C I JOHNSTON
}

From the Department of Medicine, University of Melbourne, Austin Hospital, Heidelberg, Victoria; and the ^Department of Cardiology, Prince Henry's Hospital, Melbourne, Victoria, Australia

SUMMARY Plasma concentrations of immunoreactive atrial natriuretic peptide (mean (SEM)) were measured in 135 patients admitted to two coronary care units with myocardial infarction, ischaemic chest pain, or non-ischaemic chest pain. Concentrations were significantly higher in patients with acute myocardial infarction not treated with systemic thrombolysis $(60.4(14.3) \mathrm{pg} /$ $\mathrm{ml})$ than in patients with non-ischaemic chest pain $(21 \cdot 1(4 \cdot 3) \mathrm{pg} / \mathrm{ml})$. Patients with ischaemic chest pain had intermediate values $(39 \cdot 3(7 \cdot 1) \mathrm{pg} / \mathrm{ml})$. Patients with acute myocardial infarction treated with intravenous streptokinase had normal concentrations of plasma atrial natriuretic peptide (20.2 (3.6) $\mathrm{pg} / \mathrm{mg}$ ), which were significantly lower than those in patients with myocardial infarction not given streptokinase. These changes could not be explained by factors such as age, pre-existing hypertension, renal dysfunction, or cardiac failure, nor treatment other than streptokinase. Raised plasma concentrations of atrial natriuretic peptide in acute myocardial infarction may be a homoeostatic response acting to reduce atrial pressures by natriuresis, diuresis, and venodilatation.

The lower concentrations of atrial natriuretic peptide in patients with acute myocardial infarction treated with streptokinase may reflect a short term beneficial haemodynamic effect of streptokinase.

Plasma concentrations of atrial natriuretic peptide are increased by plasma volume expansion ${ }^{1-3}$ and are higher than normal in patients with congestive cardiac failure. ${ }^{4-10}$ This increase is probably a response to atrial distension and is probably a homoeostatic mechanism to lower atrial pressures through natriuresis, diuresis, and venodilatation. ${ }^{411}$ Most studies of plasma atrial natriuretic peptide concentrations in human ventricular dysfunction have been performed in patients with chronic heart disease and overt fluid retention. We measured plasma concentrations of atrial natriuretic peptide in patients without a past history of cardiac failure when infarction was essentially complete but before appreciable volume expansion could occur. We wanted to find out whether plasma concentrations of atrial natriuretic peptide rise in response to acute left ventricular muscle dysfunction without volume expansion. We also aimed to assess the effect on

Requests for reprints to Dr P A Phillips, Department of Medicine, University of Melbourne, Austin Hospital, Heidelberg 3084, Victoria, Australia.

Accepted for publication 11 October 1988 plasma concentrations of atrial natriuretic peptide of myocardial salvage by intravenous streptokinase.

\section{Patients and methods}

Blood samples were obtained from 196 consecutive fasting patients with chest pain admitted to the coronary care units of two university teaching hospitals. Blood was drawn at $\mathbf{0 7 3 0}$ on the morning after admission before the patient got up. Patients with significantly impaired renal function (assessed by plasma concentrations of creatinine $>150 \mu \mathrm{mol} / \mathrm{l}$ ) or with a past history of cardiac failure were excluded (26 patients) because plasma atrial natriuretic peptide is known to be raised in these conditions. ${ }^{410} 12-15$ Drug treatment, including intravenous streptokinase for evolving transmural myocardial infarction (1.5 million units within four hours of the onset of chest pain) was given as required. Patients were classified as having an acute myocardial infarction if they had all of: a compatible history, appropriate electrocardiographic changes, and peak plasma concentrations of creatine kinase or creatine kinase $\mathrm{MB}$ isoenzyme 
greater than or equal to twice the upper limit of normal (upper limits of normal: creatine kinase $160 \mathrm{IU} / \mathrm{l}(2.66 \mu \mathrm{kat} / \mathrm{l})$ creatine kinase MB isoenzyme $22 \mathrm{IU} / \mathrm{l}(0.22 \mu \mathrm{kat} / \mathrm{l}))$. The infarct site was classified as anterior or inferior. Patients were considered to have ischaemic chest pain if they had anginal pain but no enzyme rise or subsequent permanent electrocardiographic changes. Patients were classified as having non-ischaemic chest pain if an alternative diagnosis was established or if after subsequent extensive investigation (for example coronary angiography) no evidence for acute myocardial ischaemia could be found. Thirty five patients who did not fulfil these classification criteria were excluded. Cardiac failure was graded as Killip class I-IV. ${ }^{16}$ The approval of the ethics committee was obtained before the study.

\section{RADIOIMMUNOASSAY FOR ATRIAL NATRIURETIC PEPTIDE}

Blood $(10 \mathrm{ml})$ was taken into chilled tubes containing edetic acid $(0.15 \mathrm{nmol})$ and 500 kallikrein inhibitor units of aprotinin (Trasylol, Bayer), placed on ice, centrifuged at $4^{\circ} \mathrm{C}$, and the plasma was stored at $-20^{\circ} \mathrm{C}$ until radioimmunoassay. ${ }^{14}$ The inter-assay and intra-assay coefficients of variation are $12.4 \%$ and $6.4 \%$ respectively. The normal range is $10-40$ $\mathrm{pg} / \mathrm{ml}$ with a lower limit of detection of $4 \mathrm{pg} / \mathrm{ml} .^{14}$

\section{STATISTICAL ANALYSIS}

Plasma concentrations of atrial natriuretic peptide were log transformed because the results were not normally distributed. We used analyses of variance and covariance, correlations, and unpaired $t$ tests on continuous variables, and $\chi^{2}$ tests on categorical variables. If a significant main effect was found by analysis of variance we measured individual differences between means by the Newman-Keuls retrospective comparisons test. Data for continuous variables are presented as means (SEM).

\section{Results}

The table shows details of the patients. The distribution of sex, systolic and diastolic blood pressure, pulse rate, or past history of hypertension was similar in all the groups. The plasma concentration of creatinine was significantly higher in patients with acute myocardial infarction treated with streptokinase than in patients with non-ischaemic chest pain $(p<0.01)$. Past myocardial infarction was more common in those with ischaemic chest pain ( $p<$ 0.001).

Plasma concentrations of atrial natriuretic peptide were significantly higher $(p<0.01)$ in those with acute myocardial infarction not treated with strep-
Table Clinical details (mean (SEM) or \%) of the patients studied

\begin{tabular}{|c|c|c|c|c|}
\hline & NICP & $I C P$ & $\begin{array}{l}A M I \\
\text { no } S K\end{array}$ & $\begin{array}{l}A M I \\
S K\end{array}$ \\
\hline $\begin{array}{l}\text { No of patients } \\
\text { Women }(\%) \\
\text { Men (\%) } \\
\text { Age (years) }\end{array}$ & $\begin{array}{l}18 \\
8(44) \\
10(56) \\
52(2)\end{array}$ & $\begin{array}{l}52 \\
24(46) \\
28(54) \\
62(1)\end{array}$ & $\begin{array}{l}43 \\
10(23) \\
33(77) \\
61 \quad(2)\end{array}$ & $\begin{array}{l}22 \\
5(23) \\
17(77) \\
54(2)\end{array}$ \\
\hline $\begin{array}{l}\text { Plasma creatinine } \\
(\mu \mathrm{mol} / \mathrm{l})\end{array}$ & 81 (3) & $88 \quad(2)$ & 91 (3) & $97 \quad(4)$ \\
\hline $\begin{array}{l}\text { Systolic blood } \\
\text { pressure }(\mathrm{mm} \mathrm{Hg})\end{array}$ & $126(2)$ & 125 (2) & 121 (2) & 121 \\
\hline $\begin{array}{l}\text { Diastolic blood } \\
\text { pressure (mm } \mathbf{~ H g})\end{array}$ & 75 (2) & 73 (2) & $72(2)$ & \\
\hline $\begin{array}{l}\text { Pulse rate } \\
\text { (beats/min) } \\
\text { No with past }\end{array}$ & 72 (2) & 73 (3) & 74 (2) & 82 (3) \\
\hline $\begin{array}{l}\text { hypertension (\%) } \\
\text { No with past myocardial }\end{array}$ & $11(61)$ & $27(52)$ & $17(40)$ & $11(50)$ \\
\hline $\begin{array}{l}\text { infarction (\%) } \\
\text { No in Killip }\end{array}$ & $3(17)$ & $34(65)$ & $6(14)$ & $4(18)$ \\
\hline $\begin{array}{l}\text { class } \mathbf{I}(\%) \\
\text { No in Killip class }\end{array}$ & $17(94)$ & $46(89)$ & $29(67)$ & $18(82)$ \\
\hline $\begin{array}{l}\text { No in Killip class } \\
>I(\%)\end{array}$ & 1 (6) & $6(11)$ & $14(33)$ & $4(18)$ \\
\hline
\end{tabular}

tokinase $(60.4(14.3) \mathrm{pg} / \mathrm{ml})$ than in those with nonischaemic chest pain $(21 \cdot 1(4 \cdot 3) \mathrm{pg} / \mathrm{ml})$ but not different from those in patients with ischaemic chest pain $(39 \cdot 3(7 \cdot 1) \mathrm{pg} / \mathrm{ml})$. The most striking finding, however, was the normal plasma concentration of atrial natriuretic peptide in patients with acute myocardial infarction treated with streptokinase $(20.1(3.6) \mathrm{pg} / \mathrm{ml})$. This was significantly lower $(\mathrm{p}<\overrightarrow{\overrightarrow{0}}$ 0.01 ) than that in patients with acute myocardial 3 infarction not treated with streptokinase. These differences were not explained by the lower age ${ }^{1718}$ of the patients with acute myocardial infarction treated with streptokinase and those with non-ischaemic chest pain compared with the other two groups $(p<$ 0.05 ), because analysis of covariance of the data on $\exists$ plasma concentrations of atrial natriuretic peptide $\dot{\delta}$ with age as covariate showed the same differences ( $p$ $<0.001)$. Nor was this difference caused by differences in treatment (intravenous fluids, long acting nitrates, $\beta$ blockers, calcium antagonists, angiotensin 0 converting enzyme inhibitors, vasodilators, digoxin, inotropes, atropine) before blood sampling as usage $\sigma$ of these drugs was similar in each group. Opiates $N$ were used more frequently in those with acute $N$ myocardial infarction treated with streptokinase, and less often in patients with ischaemic chest pain $(p<0$ $0 \cdot 001$ ). Opiates were usually administered before $\overparen{\Phi}$ admission to the coronary care unit, 8-32 hours $\stackrel{?}{+}$ before blood sampling for estimation of plasma $T$ concentrations of atrial natriuretic peptide. Treat-

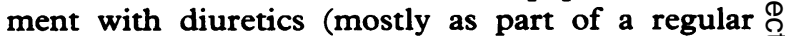
regimen for hypertension) was more common in $\mathbb{D}$ patients with ischaemic chest pain $(\underline{p}<0.05)$. 
There was an excess of patients with signs of cardiac failure (Killip class $>I$ ) in patients with acute myocardial infarction not treated with streptokinase $(p<0.05)$. Overall, plasma concentrations of atrial natriuretic peptide were higher $(p<0.01)$ in patients in Killip class II $(65.7(15.7) \mathrm{pg} / \mathrm{ml}, \mathrm{n}=24)$ than in those in Killip class $\mathrm{I}(33.9(5 \cdot 6) \mathrm{pg} / \mathrm{ml}, \mathrm{n}=110)$. There was only one patient in Killip class III and his plasma concentration of atrial natriuretic peptide was $158.8 \mathrm{pg} / \mathrm{ml}$. Patients with existing cardiac failure were excluded at the start of the trial.

There was a significant correlation between plasma atrial natriuretic peptide and age $(r=0.37, p<$ 0.001 ) but no significant correlation with plasma creatinine, probably because patients with significantly impaired renal function had been excluded. There was no significant correlation between plasma atrial natriuretic peptide and peak concentrations of cardiac enzymes.

Although plasma concentrations of atrial natriuretic peptide were slightly higher in patients with inferior infarcts $(56.2(17 \cdot 3) \mathrm{pg} / \mathrm{ml}, \mathrm{n}=34)$ than in those with anterior infarcts $(36 \cdot 4(8 \cdot 0) \mathrm{pg} / \mathrm{ml}, \mathrm{n}=31)$ this difference was not statistically significant. Similarly, there was no difference in plasma concentrations of atrial natriuretic peptide between transmural and non-transmural acute myocardial infarction.

\section{Discussion}

Atrial distension is probably the main stimulus to secretion of atrial natriuretic peptide. ${ }^{36-91920}$ In patients with chronic congestive cardiac failure ventricular dysfunction and fluid retention coexist and lead to increased atrial pressures and raised plasma concentrations of atrial natriuretic peptide. ${ }^{4-10}$ In rats with experimental infarction plasma concentrations of atrial natriuretic peptide are raised in proportion to myocardial dysfunction and infarct size ${ }^{21}$ without expansion of extracellular fluid volume. ${ }^{22}$ Similarly, we found raised plasma concentrations of atrial natriuretic peptide in patients during the acute stage of myocardial infarction before appreciable fluid retention could occur and lead to an additional increase in atrial pressures. Thus these results suggest that acute myocardial dysfunction alone, by reducing diastolic ventricular compliance and raising atrial pressures, may increase plasma concentrations of atrial natriuretic peptide. Plasma concentrations of atrial natriuretic peptide were also higher in patients in whom signs of cardiac failure developed. This result accorded with previous findings. .10 $^{-10}$ Since atrial natriuretic peptide causes venodilatation, natriuresis, and diuresis, ${ }^{411}$ raised concentrations of atrial natriuretic peptide may be beneficial in acute myocardial infarction because they will reduce cardiac preload ${ }^{23}$ and salt and water retention and so limit pulmonary oedema.

Plasma concentrations of atrial natriuretic peptide were reported in a study of patients with acute myocardial infarction. ${ }^{24}$ In that study, however, the control group was not under the same conditions of coronary care as the patients with infarcts nor were the concentrations of atrial natriuretic peptide corrected for the younger age of the controls; this may have confounded the findings of higher plasma concentrations of atrial natriuretic peptide in acute myocardial infarction. ${ }^{24}$ None the less, our study confirms and extends these findings.

Of interest was the normal mean plasma concentration of atrial natriuretic peptide in patients with acute myocardial infarction treated with streptokinase, compared with the threefold higher concentration in acute myocardial infarction patients not treated by thrombolysis. One explanation for this would be the beneficial effect of intravenous streptokinase given within four hours of the onset of chest pain in acute myocardial infarction in preserving the myocardium and myocardial function. ${ }^{25}$ Since plasma concentrations of atrial natriuretic peptide are raised in proportion to haemodynamic dysfunction $^{5-9}$ one might expect lower plasma concentrations of atrial natriuretic peptide in patients with acute myocardial infarction treated successfully with streptokinase.

Other factors might also have a role. Streptokinase catalyses the conversion of plasminogen to the protease plasmin. It is unlikely that streptokinase led to degradation of the atrial natriuretic peptide and lower plasma concentrations of atrial natriuretic peptide because streptokinase added to the assay system for atrial natriuretic peptide assay did not affect concentrations of atrial natriuretic peptide (P A Phillips, G P Hodsman, C I Johnston, unpublished observation). Streptokinase is unlikely to have had a proteolytic effect at the time of sampling because (a) streptokinase has a fibrinolytic half life of approximately 15-30 min, ${ }^{26}(b)$ blood samples for the measurement of plasma atrial natriuretic peptide were taken at least seven hours after streptokinase treatment, and $(c)$ atrial natriuretic peptide has a plasma half life of 2-3 min. ${ }^{27}$ Another factor that might have led to lower plasma concentrations of atrial natriuretic peptide after streptokinase might be the vasodilatory effects of fibrin and fibrinogen degradation products. ${ }^{28}$

A further explanation for the lower concentrations of plasma atrial natriuretic peptide in patients with acute myocardial infarction treated with streptokinase might be differing drug treatment. This too seems unlikely since opiates were the only drugs given more 
often to patients who received streptokinase, and these were usually given several hours before blood sampling. Furthermore, morphine raised plasma atrial natriuretic peptide in rats ${ }^{29}$ and so would be unlikely to lead to the lower concentrations of atrial natriuretic peptide seen in this study. Similarly, the lower concentrations of atrial natriuretic peptide cannot be explained by the lower age ${ }^{1819}$ of the patients treated with streptokinase, because analysis of covariance controlling for age showed that age was not a confounding factor. Nor does arrhythmia ${ }^{30}$ or raised blood pressure ${ }^{8}$ explain the differences in plasma concentrations of atrial natriuretic peptide across the groups because pulse rates and systolic and diastolic blood pressures were similar. The presence of other conditions that might influence plasma atrial natriuretic peptide (renal impairment, ${ }^{12-15}$ previous hypertension, ${ }^{89}$ previous myocardial infarction ${ }^{7}$ ) would also not explain the results. Patients with renal impairment were excluded, and those with the lowest plasma concentrations of atrial natriuretic peptide (those with acute myocardial infarction treated with streptokinase) had the highest plasma creatinine. Hypertension was equally prevalent across the groups and past myocardial infarction was more common in the group with ischaemic chest pain.

Patients with ischaemic chest pain had a mean plasma atrial natriuretic peptide concentration intermediate between that of patients with acute myocardial infarction and that of patients with nonischaemic chest pain. This suggests that concentrations of atrial natriuretic peptide may rise in response to ventricular diastolic dysfunction secondary to myocardial ischaemia. Unfortunately because this group had a higher prevalence of previous myocardial infarction, which might raise plasma atrial natriuretic peptide, ${ }^{7}$ as well as diuretic therapy, which might lower plasma atrial natriuretic peptide, ${ }^{10}$ these results are difficult to interpret.

In summary, the results show that plasma concentrations of atrial natriuretic peptide are raised in the acute phase of myocardial infarction. This accords with the concept that myocardial dysfunction without volume overload can lead to raised atrial pressures and release of atrial natriuretic peptide. Because atrial natriuretic peptide causes natriuresis, diuresis, and venodilatation, ${ }^{411}$ raised concentrations of atrial natriuretic peptide might therefore be beneficial by reducing cardiac preload and limiting salt and water retention and pulmonary oedema during the acute stages of myocardial ischaemia. The mean plasma concentration of atrial natriuretic peptide was normal in patients with acute myocardial infarction treated with streptokinase. This may reflect improved haemodynamic function because of myocardial salvage with streptokinase. Further studies are needed to see if the estimation of plasma $C$ atrial natriuretic peptide in the acute phase of acute $\vec{F}$ myocardial infarction is a predictor of outcome, $\stackrel{\oplus}{\rightarrow}$ especially after streptokinase treatment, and whether atrial natriuretic peptide analogues are likely to be useful in the management of myocardial infarction.

This study was supported by grants from the is National Health and Medical Research Council and $\vec{\circ}$ National Heart Foundation of Australia.

\section{References}

1 Yamaji T, Ishibashi M, Takaku F. Atrial natriuretic factor in human blood. J Clin Invest 1985;76:1705-9.

2 Sagnella GA, Markandu ND, Shore AC, MacGregor GA. Effects of changes in dietary sodium intake and saline infusion on immunoreactive atrial natriuretic peptide in human plasma. Lancet 1985;ii:1208-11.

3 Anderson JV, Donckier J, McKenna WJ, Bloom SR. The plasma release of atrial natriuretic peptide in man. Clin Sci 1986;71:151-5.

4 Tikkanen I, Fyhrquist F, Metsarinne K, Leidenius R. Plasma, atrial natriuretic peptide in cardiac disease and during infusion in healthy volunteers. Lancet 1985;ii:66-9.

5 Burnett JC, Kao PC, Hu DC, et al. Atrial natriuretic peptide elevation in congestive heart failure in the human. Science 1986;231:1145-7.

6 Raine AEG, Erne P, Burgisser E, et al. Atrial natriuretic peptide and atrial pressure in patients with congestive heart failure. $N$ Engl J Med 1986;315:533-7.

7 Lang RE, Dietz R, Merkel A, Unger T, Ruskoaho $H$, Ganten D. Plasma atrial natriuretic peptide in cardiac disease. J Hypertens 1986;4:S119-23.

8 Bates ER, Shenker Y, Grekin RJ. The relationship between plasma levels of immunoreactive atrial natriuretic hormone and haemodynamic function in man. Circulation 1986;73:1155-61.

9 Arendt RM, Gerbes AL, Ritter D, Stangl E, Bach P, Zahringer J. Atrial natriuretic factor in plasma of patients with arterial hypertension, heart failure or cirrhosis of the liver. J Hypertens 1986;4:S131-5.

10 Anderson JV, Woodruff PWR, Bloom SR. The effect of treatment of congestive heart failure on plasma atrial natriuretic peptide concentration: a longitudinal study. Br Heart $J$ 1988;59:207-11.

11 Richards AM, Nicholls MG, Ikram H, Webster MWI, Yandle TG, Espiner EA. Renal, haemodynamic, and hormonal effects of human alpha atrial natriuretic peptide in healthy volunteers. Lancet 1985;i:545-8.

12 Rascher W, Tulassay T, Lang RE. Atrial natriuretic peptide in plasma of volume-overloaded children with chronic renal failure. Lancet 1985;ii:303-5.

13 Anderson JV, Raine AEG, Proudler A, Bloom SR. Effect of haemodialysis on plasma concentrations of atrial natriuretic peptide in adult patients with chronic renal failure. $J$ Endocrinol 1986;110:193-6.

14 Ogawa K, Smith AI, Hodsman GP, Jackson B, Woodcock EA, Johnston CI. Plasma atrial natriuretic peptide: concentrations and circulating forms in 

normal man and patients with chronic renal failure. Clin Exp Pharmacol Physiol 1987;14:95-102.

15 Hasegawa $R$, Matsushita $Y$, Inoue $T$, Morii $H$, Ishibashi M, Yamaji T. Plasma levels of atrial natriuretic peptide in patients with chronic renal failure. J Clin Endocrinol Metab 1986;63:819-22.

16 Killip T, Kimball JT. Treatment of myocardial infarction in a coronary care unit. A two year experience with 250 patients. Am J Cardiol 1967;20:457-64.

17 Larochelle P, Cusson JR, Gutkowska J, et al. Plasma atrial natriuretic factor concentrations in essential and renovascular hypertension. $\mathrm{Br} \mathrm{Med} J$ 1987;294: 1249-52.

18 Ohashi M, Fujio N, Nawata $H$, et al. High plasma concentrations of human atrial natriuretic polypeptide in aged men. $J$ Clin Endocrinol Metab 1987; 64:81-4.

19 Lang RE, Tholken H, Ganten D, Luft FC, Ruskoako $H$, Unger T. Atrial natriuretic factor-a circulating hormone stimulated by volume loading. Nature 1985; 314:264-6.

20 Dietz JR. Release of natriuretic factor from heart-lung preparations by atrial distension. Am J Physiol 1984; 247:R1093-6.

21 Tsunoda K, Hodsman GP, Sumithran E, Johnston CI. Atrial natriuretic peptide in chronic heart failure in the rat: a correlation with ventricular dysfunction. Circ Res 1986;59:256-61.

22 Hodsman GP, Kohszuki M, Howes LG, Sumithran E, Tsunoda K, Johnston CI. Neurohumoral responses to chronic myocardial infarction in the rat. Circulation 1988;78:376-81.

23 Johnston CI, Hodsman GP, Harrison RW, Mendelsohn FAO, Tsunoda K. Regulation of cardiac preload by ANP in congestive cardiac failure. $\mathrm{Am} \mathrm{J} \mathrm{Med} \mathrm{(in}$ press).

24 Matsubara $H$, Nishikawa $M$, Umeda Y, et al. The role of atrial pressure in secreting atrial natriuretic polypeptides. Am Heart $J$ 1987;113:1457-63.

25 White HD, Norris RM, Brown MA, et al. Effect of intravenous streptokinase on left ventricular function and early survival after acute myocardial infarction. $N$ Engl J Med 1987;317:850-5.

26 Kohler M, Hellstern P, Doenecke P, et al. High-dose systemic streptokinase and APSAC in acute myocardial infarction: alterations of the fibrinolytic system and clearance of fibrinolytic activity. Haemostasis 1987;17:32-9.

27 Anderson JV, Struthers AD, Christofides ND, Bloom SR. Atrial natriuretic peptide: an endogenous factor enhancing sodium excretion in man. Clin Sci 1986; 70:327-31.

28 Anderson RGG, Saldeen K, Saldeen T. A fibrin(ogen) derived pentapeptide induces vasodilation, prostacyclin release and an increase in cyclic AMP. Thromb Res 1983;30:213-8.

29 Gutkowska J, Racz K, Garcia R, et al. The morphine effect on plasma ANF. Eur J Pharmacol 1986;131: 91-4.

30 Schiebinger RJ, Linden J. Effect of atrial contraction frequency on atrial natriuretic peptide secretion. $\mathrm{Am}$ J Physiol 1986;251:H1095-9.

31 Anderson JV, Gibbs JSR, Woodruff PWR, Greco C, Rowland E, Bloom SR. The plasma atrial natriuretic peptide response to treatment of acute cardiac failure, spontaneous supraventricular tachycardia, and induced re-entrant tachycardia in man. $J$ Hypertens 1986;4:S137-41. 